Abstracta Iranicacta Iranica

Revue bibliographique pour le domaine irano-aryen

Volume 28 | 2007

Comptes rendus des publications de 2005

\title{
«Attic Imported Pottery at Tel Dor, Israel: An Overview ». BASOR, 337, pp. 79-94.
}

\section{Astrid Nunn}

\section{(2) OpenEdition}

1 Journals

\section{Édition électronique}

URL : http://journals.openedition.org/abstractairanica/16462

DOI : 10.4000/abstractairanica.16462

ISSN : 1961-960X

Éditeur :

CNRS (UMR 7528 Mondes iraniens et indiens), Éditions de l'IFRI

Édition imprimée

Date de publication : 15 mai 2007

ISSN : 0240-8910

Référence électronique

Astrid Nunn, « «Attic Imported Pottery at Tel Dor, Israel: An Overview ». BASOR, 337, pp. 79-94. », Abstracta Iranica [En ligne], Volume 28 | 2007, document 119, mis en ligne le 18 septembre 2007, consulté le 25 septembre 2020. URL : http://journals.openedition.org/abstractairanica/16462 ; DOI : https://doi.org/10.4000/abstractairanica.16462

Ce document a été généré automatiquement le 25 septembre 2020.

Tous droits réservés 


\title{
« Attic Imported Pottery at Tel Dor, Israel: An Overview ». BASOR, 337, pp. 79-94.
}

\author{
Astrid Nunn
}

1 L'analyse de la céramique attique (à figures noires, à figures rouges, à vernis noir) au Levant est intéressante à de nombreux points de vue : économique pour analyser les voies de commerce, entre autres en temps de guerre ; social pour distinguer un possible choix dans l'importation de céramique grecque et en conséquence dans les formes qui intéressaient ses usagers; et socio-culturel pour en savoir plus sur ceux qui utilisaient cette céramique plus belle et plus chère que la céramique locale. Ils étaient théoriquement Levantins, marchands de diverses nationalités ou Grecs habitant le Levant. Ainsi plusieurs études ont porté sur ce sujet (cf. Abs. Ir. 20-21, c.r. $\mathrm{n}^{\circ} 182$, Abs. Ir. 23, c.r. $\left.n^{\circ} 40\right)$.

2 La céramique attique fouillée à Tel Dor (au sud de Haifa) va être publiée in extenso et l'article recensé ici n'est qu'une étude préliminaire. Dor est un des endroits de la côte et de l'arrière-pays syro-phénicien où il en a été trouvé le plus. Comme sur toute la côte, les importations débutent vers $500 \mathrm{av}$. J.-C. avec des céramiques à figures noires et vernissées noires. Vers 450 les figures rouges remplacent les figures noires et la variété des formes à vernis noir augmente. L'importation atteint son maximum au $\mathrm{IV}^{\mathrm{e}} \mathrm{s}$. et cesse vers $300 \mathrm{av}$. J.-C. En général les formes sont confinées aux vaisselles à boire et aux lécythes. Les motifs semblent refléter un goût local et ne confirment ni ne réfutent la présence de Grecs à Dor. La moitié des dessins de la figure noire représentent Dyonisos, les satires et les ménades, Héraklès et le lion de Némée apparaissent deux fois (Elaious I Painter). Plusieurs fragments de coupes et de cratères à figures rouges ont été peints par le peintre du Pithos et le Groupe Otchoët. Eux aussi montrent des scènes dionysiaques. Les lécythes proviennent du peintre d'Haimon, du groupe Lancut et de l'atelier du peintre de Beldam. La répartition des ateliers est la même que pour le reste de la Syrie-Phénicie (A. Nunn, «Der figürliche Motivschatz Phöniziens, Syriens und Transjordaniens vom 6. bis zum 4. Jahrhundert v. Chr. », OBO SA, 18, 2000, pp. 128-134). 
La valeur de cette céramique importée était telle que de nombreuses coupes furent réparées dès l'antiquité.

INDEX

Thèmes : 3.2.2. Pré-Achéménides et Achéménides

AUTEURS

ASTRID NUNN

Université de Munich 